\title{
POMPEY'S POLITICS AND THE PRESENTATION OF HIS THEATRE-TEMPLE COMPLEX, 61-52 BCE
}

\author{
Mark A. Temelini
}

\begin{abstract}
After celebrating his third triumph Pompey the Great decided to build a splendid theatre-temple complex during the political and social anxieties of the 50s BCE. This monument was an architectural undertaking hitherto never attempted at Rome. The building was designed with Rome's first permanent stone theatre, a temple of Venus Victrix and a quadriporticus. He also added a senate building in an attempt to soften senatorial antagonism. The importance of religion in the political life of Pompey demonstrates how the structure was a victory monument honouring his military achievements and represented his desire for popularity and everlasting fame. The purpose of this study is to examine the political and religious circumstances and considerations influencing Pompey's decision to present this structure to the Roman people.
\end{abstract}

In $61 \mathrm{BCE}^{1}$ Pompey celebrated one of the most extravagant triumphs Rome had ever witnessed. This third triumph mainly honoured his victorious achievements in Asia Minor, ${ }^{2}$ but also reminded the Roman spectators of his previous military campaigns in North Africa, Spain, and against the pirates in the Mediterranean Sea. ${ }^{3}$ On the social level the triumph and the games associated with it comprised a public event which catered to the people's desire for entertainment. Politically, the lavish spectacle increased Pompey's popularity by symbolizing the power and wealth which he had gained for himself and Rome. This supreme greatness and dignity was displayed in an impressive exhibition of propaganda. ${ }^{4}$ Days after the event the Roman people did

\footnotetext{
${ }^{1}$ All dates BCE unless otherwise noted.

${ }^{2}$ For a commentary on Pompey's Eastern triumph, see: Diod. Sic. 40.4; Val. Max. 8.15.8; Plin. HN 7.26.97-99, 37.5.11-7.18, 41; App. Mith. 116-117. The Fasti Capitolini (Degrassi 1954: 108), record the events of the triumph on September 29, 61 in this way: [Cn. Pompeius Cn.f. Sex. n. Magnus III] pro co(n)s(ule) a. DCXCII [ex Asia, Ponto, Armenia, Paphla]gonia, Cappadoc(ia), [Cilicia, Syria, Scytheis, Iudaeis, Alb]ania, pirateis, [per biduum pridie $k$. O]cto(bres).

3 „But what enhanced his glory the most and had never yet happened to any of the Romans," wrote Plutarch (Pomp. 45.5), „was that he celebrated his third triumph over the third continent. Even though there were others before him who had celebrated three triumphs; this man celebrated his first over Libya, his second over Europe, and his last one over Asia and he seemed in some way to have conquered the whole world with his three triumphs." In the same glorious tone Velleius Paterculus (2.40.4) wrote: "as many divisions there are of the world, he erected just as many monuments of his victory." All translations of the ancient texts are my own.

${ }^{4}$ As the triumphal procession wound its way through the Campus Martius toward the Capitoline a praefatio led the parade with the following introduction (Plin. HN 7.26.98): Cum oram maritimam praedonibus liberasset et imperium maris populo Romano restituisset ex Asia, Ponto, Armenia, Paphlagonia, Cappadocia, Cilicia, Syria, Schythis, Iudaeis, Albanis, Hiberia, Insula Creta, Basternis, et super haec de rege Mithridate atque Tigrane triumphavit. Inscribed placards and banners were carried next, listing all the captured nations, strongholds, cities, and ships, along with the numerous cities that were founded. Other inscriptions and heralds announced the millions of sesterces added to the public treasury, and the amount of money his soldiers were entitled to receive. Hundreds of captives marched alongside the wagonloads of rich plunder. Pirates, royal families, Scythian women, and hostages were led in defeat. Many lavish
} 
not easily forget the powerful image Pompey staged for himself. They regarded him as a world conqueror and formidable leader. ${ }^{5}$

In spite of all this triumph Pompey also returned to Rome under unfavourable conditions. The majority of the senate did not respect the great general. He came from a recent noble family of late distinction, he did not rise through the ranks of the cursus honorum in the venerable Roman tradition, and he was not familiar with the protocol of the Roman senate. ${ }^{6}$ Cicero provides harsh judgements about Pompey (Att. 1.13.4, 1.18.6) and comments on his general unpopularity in the senate (Att. 1.14). Many senators thought that he was unworthy of his powerful position and by unanimously denying him several contracts and official positions indicated that they did not want Pompey involved in Rome's affairs. ${ }^{7}$ Pompey was politically humiliated by the very republican establishment he faithfully served and protected during his military campaigns.

All the senatorial antagonism directed toward Pompey essentially forced him into the secret coalition with Caesar and Crassus in the summer of 60 (Cass. Dio 37.57.1-58.4). Pompey probably gained more confidence as events turned slowly towards his favour with the help of his triumviral colleagues.

In 59, Caesar used his consular powers to persuade the Tribal Assembly to ratify Pompey's bills regarding his concessions in the east and land distribution to his veterans. Pompey successfully appealed to the senate to grant Caesar a five-year military command in Gaul, and in return Caesar had appointed Pompey as a land

trophies were carried in triumph to represent every military victory, no matter how small the battle. Precious gems and minerals, pearl crowns, gold vessels, innumerable statues, and myrrh-coloured pottery (which Romans had never seen before) were displayed in triumphant glory. One huge and lavish tropaeum was even decorated in such a way as to present an image of the inhabited world. In addition, an extravagant portrait rendered in pearls of Pompey himself was displayed for the public. Behind all this wealth and victory came Pompey the Great wearing a golden wreath and full dress of a triumphator riding in a four horse chariot. We can imagine the awestruck crowds applauding in disbelief such a triumphal procession. On the social level the triumph and the ludi associated with it comprised a public event which catered to the people's desire for entertainment. The Romans loved a good show. This was probably the greatest show since Scipio celebrated a magnificent triumph over the destruction of Carthage. Pliny (HN 37.6.14) criticized it as „,austerity defeated and more truthfully extravagance [cele-

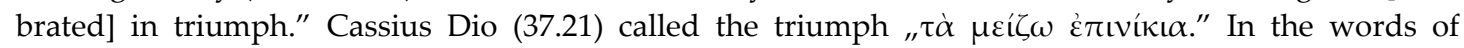
Paterculus (2.40.2) "[Pompey] surpassed the fortune of his fellow man."

${ }^{5}$ Manilius (Astron. 1.793) offered these words of grateful homage: „Pompeius orbis domitor per tresque triumphos ante deum princeps."

${ }^{6}$ Varro had to write a manual on senatorial procedure for Pompey (Aul. Gell. NA 14.17.2).

${ }^{7}$ In January 62, the Senate refused the proposal that Pompey should deal with the threat of Catiline's army (Cic. Sull. 31, Ad Brut. 1.17.1; Sall. Cat. 17.43; Suet. Iul. 16; Plut. Cic. 23, Cat. Min. 26; Cass. Dio 37.43.1) and refused to grant him a prestigious public works project (Cic. Fam. 5.7); there was senatorial opposition regarding the honour of triumphal garments and a supplicatio awarded to Pompey (Cic. Prov. cons. 11.26-27; Vell. Pat. 2.40.5; Cass. Dio 37.21.4.); Q. Caecilius Metellus Creticus was awarded a triumph by the Senate in 62 for a campaign against the pirates. This credit belonged to Pompey (Vell. Pat. 2.34.2, 2.40.5; Cass. Dio 36.17a.); Pompey's request for a deferment of the consular elections, held in July 62, was refused by the Senate, under the instigation of Cato. This request would have allowed Pompey to support, in person, the candidature of Piso (Plut. Cat. Min. 30.1-2). Pompey found it difficult to impress the Senate during his disapproval of Clodius' prosecution. Senators distrusted him so much that he withdrew in humiliation and appealed to Cicero's oratorical abilities in order to gain favourable attention (Cic. Att. 1.18); in 60, the senate defeated the ratification of Pompey's concessions in the East (App. B. Civ. 2.9), and a bill concerning the distribution of land to veterans who served in the Eastern campaigns (Cic. Att. 1.18.6, 1.19.4; Plut. Cat. Min. 30.2-3; Cass. Dio 37.49.2, 37.50.1-4.). 
commissioner in Italy. ${ }^{8}$ And, to ensure personal and political stability between the two great generals, Pompey gladly accepted Caesar's offer for his daughter's hand in marriage. Pompey would rule Rome for most of the decade. He had more military influence than Crassus, Caesar was in Gaul, and his tribunes and allies controlled the provincial armies and the Mediterranean. ${ }^{9}$

These events gave Pompey a renewed feeling of personal and political confidence within the senatorial establishment. ${ }^{10}$ Success was once again on his side. There would be another noteworthy event which would spark his desire to build a permanent theatre and therefore gain further popularity. Pompey's decision was in response to the critical views of the Roman people who were unsympathetic towards the political issues he was involved in and to gain back the favour of the masses he determined to build this monument devoted to entertainment. ${ }^{11}$ Cicero perceived the popular politicians of the triumvirate as the instigators of a grave political crisis. Pompey's level of unpopularity among the masses was observed by Cicero at the games of Apollo in July 59. He remarked that the sentiments of the people were very clearly ascertained in the theatre and at public shows where both Pompey and his advisors were maligned with hisses and verbal insults (Att. 2.19). There were even rumours of a plot to murder him. This personal abuse vented at the games persuaded Pompey to search for some form of additional popularity among the masses. In reaction to this negative sentiment he made the decision to build Rome's first permanent stone theatre. He had the power and auctoritas to do so and nobody could oppose him. ${ }^{12}$ After celebrating his third triumph in 61, Pompey already thought about a plan to build some type of permanent monument to honour his achievements. The idea arose from two noteworthy events: first he was so impressed by the theatre at Mytilene that he had sketches of it made and planned to build one like it in Rome, only larger and more splendid (Plut. Pomp. 42.4). Second, he received the privilege of wearing a gold wreath and embroidered toga at all theatrical performances, having endorsed the Roman tradition which linked politicians and the theatre. ${ }^{13}$

As construction continued in 58, Caesar departed for Gaul on a campaign which would last almost ten years. Instigated by M. Porcius Cato's remark that Pompey was ,"a dictator in all but name," Clodius' gangs began a series of humiliating verbal attacks upon Pompey and spread rumours of another assassination attempt. ${ }^{14}$ Faction fights and riots continued into 57 between Milo and Clodius.

Both factions expressed their opinion not only in the streets but also at public

\footnotetext{
${ }^{8}$ Suet. Iul. 19, 21, 54.3; App. B. Civ. 2.2.13, Mith. 114; Plut. Pomp. 48.3; Cass. Dio 38.7.5; Cic. Att. 8.3.3, 2.5.1, 2.16.2. Scullard 1982: 115.

${ }^{9}$ Syme 1939: 35.

${ }^{10}$ Rawson 1978: 106, „There is much to suggest that Pompey was active and feeling fulfilled in at least the first half of 59."

${ }^{11}$ Frézouls 1983: 204.

${ }^{12}$ Plut. Pomp. 45.5; Vell. Pat. 2.40.3-4; Manil. Astron. 1.793; Plin. HN 37.6.14; Cass. Dio 37.21.

${ }^{13}$ Since the beginning of the republic civil magistrates built temporary wooden theatres in an open area close to a temple during the annual ludi celebrations. Triumphant generals would do the same as part of their triumphal celebrations; App. B. Civ. 1.28.125; Cic. Har. resp. 12.24; Liv. 34.44.5, 34.54.4, 34.54.6-8, 41.27.5-9, 45.43.1, 48, 51, 52, 59; Plin. HN 33.52.148-149, 34.16.36, 35.8.24, 37.6.12; Tac. Ann. 14.21; Val. Max. 2.4.2; Vell. Pat. 1.13.4-5, 1.15.3.

${ }^{14}$ For Pompey and Cicero harassed by Clodius, see: Cic. Dom. 67 and 129, Sest. 69, Har. resp. 49, Pis. 28-29, Red. sen. 4; for Cato's remark, see Cic. Q. Fr. 1.2.15.
} 
theatrical events. During the games in honour of Apollo in July 57 a remarkable demonstration of the political potential inherent in theatrical occasions occurred in favour of the exiled Cicero. ${ }^{15}$ Romans from all classes demonstrated unequivocal public support for the popular orator. At the theatrical shows in the Campus Martius unanimous applause was given to senators and consuls for the decrees passed in favour of Cicero's return to Rome. Clodius had been the only official to oppose the resolutions and when he arrived at the theatre the audience shouted, cursed and made rude gestures at him. ${ }^{16}$ The longing for Cicero's return from exile was so fierce that plays were performed in his honour and actors hinted to the senators in the audience that they had erred by banning him from the city. In addition, each time there was an allusion to Cicero in a play the audience applauded enthusiastically for the return of this popular, noble and worthy Roman citizen (Cicero Sest. 56.121-57.122, 58.123). ${ }^{17}$

As Cicero reflected upon these events after his return to Rome he extolled the importance of the games as an opportunity for the expression and observation of public opinion. He was probably even dramatically pointing towards the direction of Pompey's permanent stone theatre under construction when he emphasized that "the opinion and will of the Roman people concerning public matters can be most effectually shown in three places: at a meeting, at an assembly, and at a gathering for plays" (Sest. 50.106). Pompey certainly noticed the importance of these public demonstrations and their weight in the city's affairs. His objective would be to further his popularity by gaining the support of the theatre crowds. ${ }^{18}$

In September 57 Pompey was appointed commissioner of the grain supply. He also received proconsular imperium and fifteen legates to take care of his provincial duties. Essentially, the office allowed him to remain in Rome for five years and he could supervise the completion of his theatre without any interruption of having to go abroad for military campaigns. The administrative office of grain commissioner might have in fact given Pompey the idea to enhance his theatre by adding a quadriportico which extended toward the Porticus Minucia Frumentaria. The two porticos would be closely associated with one another as victory monuments and some spaces within them served as minor locations for the distribution of grain and other commercial activities. ${ }^{19}$

\footnotetext{
${ }^{15}$ Beacham 1991: 159. The events of 57 are explained by Cicero Sest. 50.106-59.127.

${ }^{16}$ During the performance of the comedy Simulans the actors looked straight at Clodius in disapproval and chanted in a mocking tone: „For this, Titus, the end of your vicious life is in front of you" (Cic. Sest. 55.118).

${ }^{17}$ Passages from Accius' tragedy Eurysaces, read by the famous tragic actor Aesopus, expressed the grief of the people toward Cicero: „who will have helped the republic with a firm spirit?....Our most distinguished friend in our most important battle." The audience knew these lines referred to Cicero and applauded wildly. Their longing was great for the man „endowed with greatest genius." Aesopus also interpolated lines from the Andromache of Ennius: „You allow him to be banished, you cause him to be driven away, you suffer now that he has been exiled." He hinted to the Senate, Equites, and Roman people that they had erred by banning Cicero from the city; see Cic. Sest. 56.121-57.122. The longing for Cicero's return from exile was so fierce that he was even mentioned by name during the performance of the play Brutus - the line "Tullius, who had established freedom for the citizens," was encored many times over as the audience applauded enthusiastically; see Cic. Sest. 58.123. Seager 1982: 328-338. ${ }^{18}$ Frézouls 1983: 203-204.

${ }^{19}$ Marcus Minucius Rufus, consul in 110 and proconsul in Macedonia, won major victories, held a triumph in 106 and built the Porticus Minucia as his victory monument. It became the main distribution
} 
Similarly, there is an event which might have encouraged him to add a senate house. According to Roman law, Pompey could not attend a meeting of the senate within the wall of Rome as grain commissioner holding imperium. But a case arose in February 56 regarding Milo and the senate held its meeting in the temple of Apollo (close to his theatre) in the Campus Martius so that Pompey could attend (Cic. Q. Fr. 2.3.1-4). ${ }^{20}$ When the senate came to him, Pompey decided to add a curia to his theatre complex at this time, a year prior to its grand opening. ${ }^{21}$ Through his goodwill and attempting to gain the senate's approval, he honoured the senators with the construction of a senate house within the walls of the theatre complex which became known as the curia Pompeia. When the senate house in the Roman forum was burned down by rioters in 52, following the assassination of Clodius, Pompey's curia gained new recognition. It became so important that it was the only structure outside the sacred forum area to actually be called a curia.

In 55, the consulship of Pompey and Crassus began amid a certain amount of political turmoil. Many senators were opposed at giving extensive provincial commands to both generals. Opposition was so fierce that it spilled into the streets where statues of Pompey were attacked by the urban mob. ${ }^{22}$ However, no matter what difficulties Pompey had encountered with his opponents, whether from the senate or mob, his popularity was about to receive a great boost. When the temple of Venus Victrix, was finally completed on August $12,55,{ }^{23}$ a massive building complex with

centre for grain under the emperor Claudius (see Stambaugh 1988: 69, 334 n. 2, 353 n. 10). The quadriporticus post scaenam built by Agrippa for the theatre at Ostia provides an almost contemporary example for the function of Pompey's portico. Agrippa's double-colonnaded portico enclosed a garden and a small temple serving as a retreat for the audience (according to the precepts of Vitruvius De arch. 5.9). But, located about one hundred metres from the Tiber river it also served as a centre for commercial activities called the Piazzale of the Corporations and divided into sixty-one stationes. Local merchants, shipwrights and foreign clients owned many of these offices. The portico resembled some of the early public, commercial warehouses (horrea) which contained storage rooms that opened off into porticoed courtyards near the river. In Rome this plan was well established in the republican Horrea Galbae and Augustan Horrea Agrippiana near the Forum (Pavolini 1983: 64-69, Ward-Perkins 1981: 143, Sear 1987: 130). The horrea at Ostia stored commodities such as grain, vines and olives before they were reshipped to Rome. The Campus Martius had already been the preferred location for the display of eight previously constructed porticos. They were commemorative structures dedicated by triumphant republican generals and civil magistrates in the second century designed to enhance the beauty of the Roman landscape. All of them were located very close to Pompey's complex and decorated with many Hellenistic works of art. Three surrounded temples, four were in close proximity to temples, and one was near the dockyards. The interior of Pompey's portico was decorated with trophies, statues and gardens and the exterior was divided into stationes for the local guilds and commercial store rooms for the local distribution of grain (La Rocca 1987-88: 287). Modern street names honour the ancient and medieval workshops that were in the area (see below n. 24). Negotiantes showed their appreciation by honouring Pompey with a statue placed somewhere near the portico (Degrassi 1965: 114-115 and fig. 163).

${ }^{20}$ Rawson 1978: 122-123.

${ }^{21}$ The room would house six hundred senators. Pompey received much recognition for providing Rome with such a magnificent curia. In 54, Cicero made an allusion to Pompey's theatre and curia while referring to the theatre at Rhodes as the place for Greek assemblies (Rep. 3.48), "et in theatro et in curia res capitales et reliquas omnis iudicabant idem." Pompey had observed that contiones and comitia could be transferred to his theatre (Cic. Sest. 50.106), so why not the curia also? As early as 54, Caesar reacted to Pompey's action by having the idea to build a Saepta (a meeting and voting area) right beside the theatre and planned to build another theatre in the same vicinity; Taylor 1966: 31; Ward-Perkins 1981: 22, $23,25$. 22 Plut. Cat. Min. 43; Cass. Dio 39.33.6.

${ }^{23}$ For the date of the Temple of Venus Victrix, see Degrassi 1963: 493. 
magnificent harmonious proportions, whose total area was approximately the same as the Roman Forum, had been created. ${ }^{24}$ With the addition of his own senate house in the quadriportico he had symbolically created a functional „Forum Pompeium."

Located in the lower Campus Martius, the whole complex faced east as did most traditional Greek temples and sanctuaries. ${ }^{25}$ It was directed towards the valley between the Cispian and Esquiline hills - the Subura district. Beyond this point, it was oriented towards the large theatre-temple complexes of Praeneste, Gabii, and Tibur (less than fifty $\mathrm{km}$ east of Rome). The Porticus Minucia and its enclosed four temples acted as the monument's sacred façade. ${ }^{26}$ Once the finishing touches were added to this aesthetic architectural masterpiece, unique in size and dimension ${ }^{27}$ and containing exceptional decoration, ${ }^{28}$ Pompey inaugurated his theatre complex at the end of September with great fanfare. ${ }^{29}$

In his quest for pietas Pompey promoted his cult of Venus Victrix in connection with his theatre. He manipulated the powerful cult by demonstrating to the Roman people that Venus was the epitome of victory and that Rome was safe under her protection. According to Tacitus (Ann. 14.20.4-6) many Romans could not accept Pompey's theatre because it made the sacred area of the Campus Martius profane by

\footnotetext{
${ }^{24}$ For the plan and scale of: i) the Roman Forum see Lugli 1968: 80; ii) the theatre of Pompey see Etienne 1977: 73. The Roman Forum was approximately 52500 sq. m. and Pompey's theatre complex measured approximately 48000 sq. m. A representation of Pompey's monumentum is outlined on the Severan marble plan (Almeida 1981: 148 and table 32; Reggiani 1985: 369-375). Although its ancient, physical superstructure has disappeared it is one of the few Roman monuments whose form has been preserved in modern Rome's urban topography, marked by: Piazza Campo dei Fiori, via dei Giubbonari, via dei Chiaviri, Piazza Grotta Pinta, via Sant'Anna, via delle Botteghe Oscure, via Sudario, via dei Falegnami, Largo di Torre Argentina.

${ }^{25}$ Examples of some remarkable Greek temples which faced east include: the Hephaisteion overlooking the Athenian Agora, the magnificent Parthenon and the monumental entranceway of the Propylaia on the Acropolis at Athens, the temple of Apollo at Delphi, and the large temple of Zeus at Olympia.

${ }^{26}$ The four temples were dedicated to: Iuturna, Fortuna Huiusce Diei, Feronia, and Lares Permarini.

27 The theatre was known as the theatrum lapideum or marmoreum from the local materials of which it was built. The exterior façade was composed of three stories of arcades with twenty-four arches each. An arrangement of three superimposed column orders (Tuscan, Ionic, Corinthian) and entablature adorned the arcades. An aesthetic columnar progression enhanced the theatre's exterior beauty. This was the first permanent structure at Rome to adopt this pattern of superimposed orders. The Temple of Venus, projecting outwards (Gagliardo and Packard 2006: 112 n. 60), was raised approximately forty-two metres high on a lofty podium above the cavea and facing the stage. The theatre itself was thirty-five metres in height, and 150 metres in diameter. The cavea had a capacity of about 25,000 people. The scaena was 95 metres long and about ten metres deep. The first scaena frons may have been wooden (Marchetti-Longhi 1936: 258-259; Crema 1959: 85, 95; cf. Gleason 1994: 21-24). The quadriportico was $180 \mathrm{~m} \times 135 \mathrm{~m}$. According to Vitruvius (De Arch. 5.9.1) the section of the portico behind the stage was set up as a choragium. Exedrae were used as store-rooms for stage properties and costumes, and as rehearsal halls for the chorus and actors. The theatre and temple were almost equivalent in height to the Capitoline hill and the Temple of Jupiter Capitolinus respectively; for dimensions and height equivalents see Coarelli 1974: 256; Lugli 1968: 3, 6.

${ }^{28}$ The decoration of the complex (including the statue of Pompey in the curia, and the statuary and booty from military campaigns) and the building of Pompey's new house beside it are testimony to the general's political image; see notes 45 and 49 below, Frézouls 1983, Rawson 1978: 98-138.

${ }^{29}$ The grand opening was announced by Cicero (Pis. 65) who also provides a vivid account of the festivities with some disdain (Fam. 7.1). The inaugural celebrations were successfully popular except for the debacle of the elephant slaughter, which turned the crowd against Pompey, and the events were expressively described by Pliny (HN 8.20.53, 8.24.64, 8.28.70, 8.30.72, 8.34.84), Plutarch (Pomp. 52), and Cassius Dio (39.38).
} 
establishing a permanent location for a structure dedicated to entertainment. In response to this conservative attitude Pliny (HN 8.7.20) tells us that Pompey held the inaugural games of his whole structure as the "dedication of the temple of Venus Victrix." Since Pompey was afraid of the censorial punishment of his memory and striving to gain more popularity he did not proclaim it a theatre but merely a temple of Venus ",underneath which steps of theatre seats were built” (Tert. De spect.10). ${ }^{30}$

The importance of religion in the political life of Pompey concentrated on the impact of the goddess Venus Victrix and precisely her relationship with victory. ${ }^{31}$ The particular temple vowed by Pompey and dedicated in connection with all his triumphs demonstrated a true religious sense of obligation to the goddess. He rallied her support in 80 when he celebrated his first triumph. ${ }^{32}$ And, again in 55, at the moment when his power was at its height, he solemnly dedicated a temple to the goddess.

The ability to harness the power of a principal deity such as Venus was a matter of personal advantage. The knowledge that Lucretius had dedicated his work On the Nature of Things to the influential goddess was not coincidental. ${ }^{33}$ This Italian goddess was not only acknowledged by Varro (Ling. 6.33) as charming and beautiful, but also as a victorious deity for Pompey and a conqueror of nations for the Roman people. ${ }^{34}$ In the second and first centuries, the belief that Venus gave victory to the descendants of the Trojans was exploited by Roman noble families such as the Julia and Memmia. These families claimed Venus as their patron goddess of victory and divine ancestor by representing her on their personal coins. ${ }^{35}$

\footnotetext{
${ }^{30}$ On the ban on permanent theatres and Pompey's justification for building his theatre, see Beacham 1999: 61-71; Campbell 2003; and Leach 2004: 102, on P. Cornelius Scipio Nasica's senatus consultum prohibiting anyone "to offer seats for spectators within a one mile (passus mille) radius of Rome" (Val. Max. 2.4.2).

${ }^{31}$ In the hellenistic period, Nike is used for political ends by Alexander the Great and the Diadochi on coins, gems, and in military ceremonies (Plut. Sull. 11.1-2; Préaux 1978: 181-183; Cerfaux 1957). The goddess is represented in statues and vase paintings but she did not receive her own cult and temple. During the Roman republic, Victoria received a temple, cult, and festival rite as early as 294 (Liv. 10.33.9) which fully integrated her into the Roman community. For the fundamental differences between modest Nike and the practical nature of Roman Victoria, see Weinstock 1957: 212-229.

32 Schilling 1954: 285-286.

33 Boyancé 1950: 219-221.

${ }^{34}$ The Romans considered Venus to be their privileged representative whose intervention always resulted in a triumph. Ever since the first Punic war, when the Romans defeated the Carthaginians at the battle of Eryx in Sicily in 248 and occupied the Temple of Venus, Rome's imperial destiny was determined and Venus was elevated to a national deity. They considered themselves as the true inheritors of the Venus Erycina cult in Sicily because of their victorious resistance at the summit of Mount Eryx. The Romans were under the patronage of the goddess who brought them victory and linked them to their Trojan ancestry; Polyb. 1.55, 1.58.7-8, 2.7.9-10; Diod. Sic. 4.83.4; Dion. Hal. Ant. Rom. 1.52.3-4, 1.53.1-3; and Schilling 1954: 93-117, 241. Venus had been officially honoured in 217 as a participant at the banquet of the gods. Twelve of the most important Roman deities, divided into couples, engaged in a religious feast. Appropriately paired with Venus was Mars. The national quality of the two partners had been of intrinsic importance for the Romans: Mars was the warrior god and conqueror, whereas Venus was the tutelary power and protector. Mars and Venus were Rome's guardians, inspiring their offspring (i.e. the Roman nation) to strive for victory over all; Schilling 1954: 207-208. But none of the handful of temples dedicated to Venus prior to Pompey's was located in the Campus Martius to honour Venus' close association with Mars; For temples and shrines dedicated to Venus see Platner and Ashby 1929: 551-555; Schilling 1954: 210-219; Stambaugh 1988: 110, 214.

${ }^{35}$ For families adopting Venus see: Dion. Hal. Ant. Rom. 1.85; R. Schilling, p. 272; Evans 1992: 28, 31, 39, $152,153$.
} 
Sulla, the soldier and statesman, was driven by a mystical belief in his luck and understood the propagandistic worth of divine patronage. He proclaimed himself to be the privileged protégé of Venus, not by genealogical descent but by a self-determined, autocratic worthiness. The choice of the surname Felix linked Sulla personally into a special relationship with Venus. Throughout his career Sulla attributed his luck to the special protection of his patron goddess. In appreciation for her favourable kindness he gave himself the Greek title of "epaphroditos” („favoured by Venus"). ${ }^{36}$ When Sulla returned to Rome from the East in victory he made an official consecration to the goddess who aggrandized his power. He placed himself under the auspices of Venus and dedicated a Temple to Venus Felix. The goddess' name was also inscribed beside those of Mars and Victoria, thus emphasizing her victorious capabilities (Plut. Sull. 19.9).

To enhance his own popularity, Pompey continued this tradition and added his own personal touches. A new boastful modifier (i.e. Victrix) had been added to his patron goddess, which expressed his devotion to military success under her protection. ${ }^{37}$ The invocation of Victrix is justified by the Greek myth that Venus was victorious over Minerva and Juno at the judgement of Paris (Ov. Fast. 4.119-124). Similarly, Venus was Victrix over Pompey's Minerva to whom he had vowed during the wars against Mithridates, and Rome's Juno and Minerva, the two great goddesses of the state. Pompey took this exploitation to a symbolic height: as the Temple of Venus Erycina stood on a hilltop both in Sicily and in Rome so now did Pompey's Venus Victrix at a height equal to the sacred Capitoline hill. Venus dominated the theatre on the top of the cavea which served as the staircase to the temple and sponsored the three triumphs of Pompey. Venus the victorious was appropriately placed high above the realm of her partner Mars, the Campus Martius, surveying the field where battles were proclaimed, generals returned in triumph, and triumphal monuments were dedicated. ${ }^{38}$

Pompey's Temple to Venus Victrix was the product of a theology of victory which had been established by Sulla. Pompey's triumphal career relied on the same victorious principles as Sulla's (principles which would also be adopted by Caesar and Augustus): Pompey, like Sulla, was an ambitious general who enhanced his power and auctoritas by joining the priestly college of augurs and earned victorious favours from Venus. ${ }^{39}$ But the one event that Pompey did not possess, which Sulla had to his credit, was to have his own ludi victoriae recognized in the Roman calendar.

Sulla had set a precedent by having this obscure Italian goddess suddenly intervene in military affairs. Her victorious mystique inspired generals to succeed. ${ }^{40} \mathrm{It}$ is in the cult of Venus that Pompey appears to be the heir of Sulla. Although Pompey

\footnotetext{
36 Schilling 1954: 272-275, 284-289; Plut. Sull.3, 6.1-6, 6.9-10, 34.3-5, 35.2; App. B. Civ. 1.97; Aul. Gell. NA 10.15 .

${ }^{37}$ According to Sauron (1987: 463) Pompey presented himself as "the representative of Venus of Troy, victorious at the judgement of Paris, and by this title protectress of Rome and guarantor of the victories of the imperator."

${ }^{38}$ For complete information regarding the generals, their triumphs, votive temples, commemorative porticos, and plundered artwork in the southern Campus Martius refer to: Wiseman 1974: 3-26, Coarelli 1977: 1-23, and Versnel 1970.

${ }^{39}$ Gagé 1933: 1-43.

40 Schilling 1954: 296; Plut. Luc. 12.2-4.
} 
was one of the first generals to undermine Sulla's constitutional policies after his death, he still admired the former soldier-statesman and thought of him as his role model. Certain allusions by Cicero show that Pompey constantly thought about Sulla's achievements and tried to compare himself to him. ${ }^{41}$

When Sulla established his ludi Victoriae Sullanae from October 26 to November 1 in 81 as a permanent event in the religious calendar of Rome he enacted his own religious holiday in honour of the goddess Victoria and Venus Felix and in honour of his successful military campaigns. Under his rule Rome was free from its enemies. ${ }^{42}$ He held Victoria and Venus, and the qualities of victory they represented, in his exclusive possession. His own ludi guaranteed that his exploits would be remembered by the Roman people. It was the first time that a Roman general had connected his name to the sacred ludi, thus displaying a strong desire to be associated with the deities of victory..$^{43}$

Pompey observed the triumphal monopoly Sulla held over the goddess and his ambition drove him to be greater than his predecessor. Throughout his whole military career Pompey held extraordinary commands which were hitherto unprecedented and facilitated his acceptance into consular office. But it was his membership in the augurate through which Pompey was able to project his power. As Sulla did before him, Pompey placed the augural priesthood at the foundation of his power and authority (Cic. Leg. Man. 10.28). Along with his military know-how and personal merit Pompey exhibited extraordinary luck (felicitas). According to Cicero (Leg. Man. 16.47-49), Pompey was favoured by the gods and inspired by the victorious aspect of Sulla's felicitas which corresponded to Pompey's luck. ${ }^{44}$

Pompey's supreme imperium had been directed by a sense of public duty and inspired by the theological belief that his power was justified under the worship of Venus, her association with victory, felicitas, and the augural priesthood. Cicero (Leg. 2.12.31-33) pointed out the great powers of the augurs: "the most highly esteemed and most distinguished duty in the republic is that of the augurs, since it is a position linked to auctoritas." A similar passage in his work the Republic (2.9.16) praises the obedience that must be shown toward the importance of the auspices.

The functions which Pompey's temple fulfilled are revealed by the qualities of the name Victrix. It served as a reminder of the extraordinary overseas victories achieved by the general. As the architectural focus of the building complex, the temple dominated Rome's first stone theatre and the enclosed colonnaded space which expressed Pompey's ambitious interests. ${ }^{45}$

\footnotetext{
${ }^{41}$ Cic. Att. 9.7.3, 9.10.2, 9.10.6.

42 Sulla was victorious in the First Mithridatic War (88-84), and when he returned to Rome in 82 he defeated Marcellus at the battle of the Colline gate thus ending the Civil war. He celebrated a triumph for his eastern campaigns on January 27 and $28,81$.

${ }^{43}$ Sulla's festival was the first addition in 92 years (since 173) to the group of six traditional ludi which the Roman Republic had decreed in honour of the gods. The fact that his ludi lasted well into the Empire affirms that the Roman people never forgot Sulla's name.

${ }^{44}$ Gagé 1933: 40-41.

${ }^{45}$ Pompey was one of the first Republican generals at Rome to exhibit allegorical statues which personified the nations he conquered (Suet. Ner. 46). Precedent was found in the Hellenistic centres of Pergamum, Alexandria and Antioch whose statuary commemorated victorious battles (Boardman 1985: 108). Pompey had been influenced by this Hellenistic monumental sculpture and a popular name for a
} 
By placing the whole construction under the protection of Venus Victrix Pompey recognized the role religion played in the festival celebrations. And if he intended to continue to celebrate his own ludi victoriae he needed a powerful cult under which to dedicate the games. Pompey might have wanted to follow Sulla's lead since the latter had incorporated and celebrated the ludi victoriae Sullanae in the Circus Flaminius region of the Campus Martius. The same area where Pompey built his theatre complex.

Did Pompey the Great want his theatre to be primarily a setting for the celebration of his own ludi victoriae in connection with Venus Victrix? Unlike contemporary Roman noble families, Pompey was not concerned with claiming Venus as a divine ancestor. When he married Caesar's daughter, he chose not to take the opportunity to exploit the divine lineage of the Julian family. Pompey did not follow the trend of depicting Venus on the coinage he issued under his own name which would have been a sure sign of interest in divine ancestry. ${ }^{46}$ Pompey was only concerned with Venus' victorious aspect.

In commemoration of the foundation of the new Venus cult, a denarius was issued in 54 by Faustus Sulla, Pompey's son-in-law. On the obverse side of the coin, Venus Victrix is adorned with the appropriate symbols of military victory: a diadem, laurels, and a sceptre. On the reverse, three trophies represent Pompey's three triumphs over Africa, Europe, and Asia. According to Cassius Dio (42.18.3) these were the same three trophies displayed on Pompey's signet ring. In addition, the sacred ewer and staff represented on the coin symbolize Pompey's dignity as an augur. ${ }^{47}$ After resolving two years of intense civil strife in Rome in 52, Pompey held his third consulship and as augur made an offering to the goddess Victoria in the Temple of Venus Victrix on August 12 (Aul. Gell. NA 10.1.7). He was so preoccupied with the power of Venus Victrix that on the eve of the battle of Pharsalus (in 48) he "dreamed that the people applauded when he walked into his theatre and that he adorned the Temple of Venus Victrix with many spoils of war" (Plut. Pomp. 68.2). Since it was always the custom to observe the anniversary of any important temple with a festival Pompey might have attempted to establish his own ludi victoriae Pompeianae in honour of Venus Victrix. ${ }^{48}$

The temple as well as the whole complex functioned as a museum advertising Pompey's connection with Venus and the other divinities representing the qualities he needed for his victories. Among other dedications were trophies, statues, and paintings. ${ }^{49}$ The nature of the deity made the location in the Campus Martius appropriate.

certain section of the portico was porticus ad nationes, an area which glorified his conquest of the Mediterranean lands and beyond (Plin. HN 36.4.41).

${ }^{46}$ Dion. Hal. Ant. Rom. 1.85; Schilling 1954: 272; Evans 1992: 28, 31, 39, 152-153.

47 For a representation of Pompey's coin, see Grueber 1970: 489 and plate 48, \#22.

${ }^{48}$ The temple was the site of annual religious ceremonies. Pompey, as augur, presided at the sacrifices, made dedications and took the auspices from this site. The victorious general proudly displayed his triumphal sceptres and wreaths in the temple alongside some of the military standards obtained from the enemy (Charles-Picard 1957: 181-190, Prop. 2.32.11-12). Thus, the temple acted as a triumphal armory.

${ }^{49}$ Pliny (HN 35.35.59, 35.37.114, 35.40.126, 35.40.132) provides a description of the wall paintings and sculptures, all located in exedrae and between columns in the portico. Along with his collection of gems and precious stones, Pompey was also a passionate collector of extraordinary works of art by famous Greek painters and sculptors of the fifth and fourth centuries. He displayed most of them in his monumentum but also in other temples throughout Rome (such as the Temples of Hercules and Minerva). 
She was in the same area as the other war gods such as Bellona, Mars, Jupiter Stator, and Juno Sospita. The temple represented Rome's contact with the outside world. Pompey placed the temple high above the complex for its visual impact and powerful propaganda. The Temple of Venus Victrix, in a dominant axial position at the west end of the complex, joined divine victory with a new and useful public space just outside the Roman forum.

These functions reflect Venus' role as goddess of victory, and with every victory came triumph and entertainment. The solemn day of dedication of this large temple would have been observed each year with a proclamation of a day of celebration. Since the celebrations would be in honour of Venus, then, in effect, the festival would theoretically be considered as ludi victoriae. The Circus Flaminius region would have been appropriate since this was already the area where Sulla's victory games were celebrated. But in order to have his own public games incorporated into the Roman calendar Pompey would have had to gain the senate's approval. One particular way he attempted to do this was by honouring the senators with the construction of another senate house attached to his complex beyond the Roman forum.

The ludi victoriae of both Sulla in 81 and Caesar in 46 were dedicated in honour of the end of civil strife and symbolized the restoration of Roman order. Similarly by 52, Pompey became sole consul and de facto dictator in everything but name. He held a wide ranging command and helped to put an end to the civil disorder by passing numerous laws and by having Milo prosecuted for Clodius' murder. ${ }^{50}$ In appreciation for having secured the support of the senate and re-establishing a state of order he made a sacrifice in the Temple of Venus.

If Pompey had been concerned with pre-eminence, then he would have followed Sulla's lead and try to institute his own victory games..$^{51}$ The festival would have been appropriately celebrated each year on the date of the temple's dedication (August 12) - except that the tense political situation in Rome between the optimates and dynasts did not yet warrant adequate justification for Pompey's victory games..$^{52}$ When Caesar dismissed the senate's ultimatum to relinquish his commands in Gaul and in defiance crossed the Rubicon in early January 49, Pompey was invited by the senate to defend the Republic.

After the completion of Pompey's theatre-complex, Cicero stressed that great virtues had to be displayed to the public in great theatres (Rab. Post. 42). Anyone who sought immortality had to perform great achievements which ultimately would be governed by the people's ability to recollect them effectively. Everyone in Rome observed that Pompey's theatre complex was an original Roman design worthy of much praise. ${ }^{53}$ This extraordinary monument had a town-like quality where all classes of

\footnotetext{
Among the tabulae in the portico there was a painted battle scene by Polygnotos of Thasos; a painting of Cadmos and Europe attributed to Antiphilos; a large picture by Pausias of the sacrifice of oxen; and Nicias the Younger painted the great Alexander and a seated Calypso. Narrative triumphal paintings or friezes (tabulae triumphales) of military victories were gazed at and admired by passers-by and young men aspiring to continue the Roman tradition of victory; see Kuttner 1999.

${ }^{50}$ Rawson 1978: 140-141; Taylor 1949: 148-152.

${ }^{51}$ Cf. Knight 1968: 878-883.

52 Taylor 1949: 152-161.

53 The Greek geographer Strabo was so impressed with the beauty of the theatre complex that he commented how Pompey "had outdone all others in his zeal for buildings and expense incurred" (5.3.8). The building complex was so unique that 250 years after its construction Dio Cassius (39.38.1) reports
} 
people could gather. ${ }^{54}$ It symbolized his quest to "always be the best and excel over others." 55 The Roman Alexander exerted his powers as a Republican princeps and allowed no one to be equal to him (Luc. 1.103-126). The monument helped him gain recognition and was a channel for self-glorification which reminded everyone in Rome of Pompey's extraordinary military achievements. It could be seen from any hilltop in Rome. The power of the goddess Venus Victrix in her own temple situated on the summit of the cavea indicated Pompey's triumph "over the whole world." 56 It exemplified the competitive Roman spirit which drove generals and politicians to be the best, greatest and first above all. ${ }^{57}$ It added a new aspect to Rome's urban topography and set the standard for the monumental architecture of the imperial age. The theatre complex reinforced the republican idea that the pursuit of individual honour and glory was urged on by an intense desire for fame and popularity.

\author{
Dr. Mark A. Temelini \\ Department of Classics, Modern Languages \& Linguistics \\ Concordia University \\ Montreal, Canada \\ E-mail:markteme@alcor.concordia.ca
}

\title{
Bibliography
}

Almeida, E. R. (1981) Forma urbis marmorea: aggiornamento generale 1980. Roma: Quasar. Beacham, R. C. (1991) The Roman Theatre and Its Audience. London: Routledge.

Beacham, R. C. (1999) Spectacle Entertainments of Early Imperial Rome. New Haven: Yale University Press.

Beacham, R. C.; Denard, H. (2003) 'The Pompey Project: Digital Research and Virtual Reconstruction of Rome's First Theatre.' - Journal of Computers and the Humanities 37.1, 129-140.

Boardman, J. (1985) Greek Art. London: Thames and Hudson.

Boyancé, P. (1950) 'Lucrèce et son Disciple.' - REA 52, 212-233.

Campbell, C. (2003) 'The Uncompleted Theatres of Rome.' - Theatre Journal 55.1, 67-79.

Cerfaux, L.; Tondriaux, J. (1957) Le culte des souverains. Paris: Desclée.

Charles-Picard, G. (1957) Les trophées romains. Paris: Boccard.

Coarelli, F. (1971-72) ‘Il complesso Pompeiano del Campo Marzio e la sua decorazione scultorea.' - RPAA 44, 99-122.

\footnotetext{
that the Romans still took pride in it. The last textual trace was by Cassiodorus (Var. 4.51.3-4) who documents the restoration of the theatre (between 507 and 511) during the reign of King Theoderic.

${ }^{54}$ Gros 1987: 325, 347: „nous dirons que rien n'évoque mieux le déplacement effectif des centres de la convergence populaire, et les nouvelles modalités de l'exercice du pouvoir, que ces edifices (i.e. théâtres) où le Princeps se donne à lui-meme et au peuple rassemblé le spectacle d'une puissance sacralisée."

55 This advice was given to Pompey by the Greek philosopher Poseidonius (Strabo Geogr. 11.1.6). The quotation is attributed to Homer, Iliad 6.208 and 11.784. It was also Cicero's maxim (Q. Fr. 3.6.4).

${ }^{56}$ Anth. Lat. entry \#402: „Pompeius totum victor lustraverat orbem.” Cf. Plut. Pomp. 45.5, Vell. Pater. 2.40.4, Manilius, Astron. 1.793.

57 Wiseman 1985: 3-10
} 
Coarelli, F. (1974) Guida archeologica di Roma. Verona: Mondadori.

Coarelli, F. (1977) 'Public Building in Rome Between the Second Punic War and Sulla.' Translated by Michael H. Crawford. - PBSR 45, 1-23.

Crema, L. (1959) L'architettura romana. Torino: Soc. ed. internazionale.

Degrassi, A. (1954) Fasti Capitolini. Torino: Paravia.

Degrassi, A. (1963) Inscriptiones Italiae, vol. 13. Roma: Ist. Poligrafico e Zecca dello Stato, Libreria dello Stato.

Degrassi, A. (1965) Inscriptiones Latinae Liberae Rei Publicae: Imagines. Berlin: de Gruyter.

Etienne, R. (1977) ‘La curie de Pompée et la mort de César.' - Hommage à la mémoire de Jérôme Carcopino. Paris: Les Belles Lettres, 71-79.

Evans, J. D. (1992) The Art of Persuasion: Political Propaganda from Aeneas to Brutus. Ann Arbor: University of Michigan Press.

Frézouls, E. (1983) ‘La construction du theatre lapideum et son contexte politique.' Théâtre et spectacles dans l'antiquité. Leiden: Brill, 193-214.

Gagé, J. (1933) ‘La théologie de la victoire impériale.' - Rev. Hist. 171, 1-43.

Gagliardo, M. C.; Packer, J. E. (2006) 'A New Look at Pompey's Theater: History, Documentation, and Recent Excavation.' - AJA 110, 93-122.

Gleason, K. L. (1994) 'Porticus Pompeiana: A New Perspective on the First Public Park of Ancient Rome.' - Journal of Garden History 14, 13-27.

Greenhalgh, P. (1980) Pompey: The Roman Alexander. London: Weidenfeld and Nicolson. Greenhalgh, P. (1981) Pompey: The Republican Prince. London: Weidenfeld and Nicolson.

Gros, P. (1987) ‘La fonction symbolique des édifices théâtraux dans le paysage urbain de la Rome Augustéenne.' - L'urbs: espace urbain et histoire. Roma: Boccard, 319-343.

Grueber, H. A. (1970) Coins of the Roman Republic in the British Museum. London: British Museum.

Hanson, J. A. (1959) Roman Theater-Temples. Princeton: Princeton University Press.

Hill, D. K. (1944) 'The Temple above Pompey's Theater.' - CJ 39, 360-365.

Knight, D. W. (1968) 'Pompey's Concern with Pre-eminence after 60 B.C.' - Latomus 27, 878-883.

Kuttner, A. L. (1999) 'Culture and History at Pompey's Museum.' - TAPA 129, 343-373.

Leach, E. W. (2004) The Social Life of Painting in Ancient Rome and on the Bay of Naples. Cambridge: Cambridge University Press.

La Rocca, E. (1987-88) 'Pompeo Magno «novus Neptunus».' - BCAR 92.2, 265-292.

Lugli, G. (1968) Roma antica, il centro monumentale. Roma: Bardi.

Marchetti-Longhi, G. (1936) “Theatrum lapideum,' 'curia pompeia' e 'trullum Dominae Maraldae' (topografia antica e mediovale di Roma).' - RPAA 3 (12), 233-319.

Pavolini, C. (1983) Ostia. (Guide archeologiche Laterza; 8.) Roma; Bari: Laterza.

Platner, S. B.; Ashby, T. (1929) A Topographical Dictionary of Ancient Rome. London: Oxford University Press.

Préaux, C. (1978) Le monde hellénistique. Paris: Presses Univ. de France.

Rawson, B. (1978) The Politics of Friendship: Pompey and Cicero. Sydney: Sydney University Press.

Reggiani, A. M. (1985) 'Ipotesi di recupero del teatro di Pompeo.' - Roma: archeologia nel centro: II, La "città murata". Roma: de Luca, 369-375.

Richardson, Jr., L. (1987) 'A Note on the Architecture of the Theatrum Pompei in Rome.' - AJA 91, 123-126. 
Richardson, Jr., L. (1992) A New Topographical Dictionary of Ancient Rome. Baltimore: Johns Hopkins University Press.

Sauron, G. (1987) ‘Le complexe Pompéien du Champ du Mars: nouveauté urbanistique à finalité idéologique.' - L'urbs: espace urbain et histoire. Roma: Boccard, 457-473.

Schilling, R. (1954) La religion romaine de Vénus depuis les origines jusqu'au temps d'Auguste. Paris: Boccard.

Scullard, H. H. (1982) From the Gracchi to Nero: a History of Rome from 133 B.C. to A.D. 68. 5th ed. London; New York: Methuen.

Seager, R. (1982) 'Cicero and the Word popularis.' - CQ n.s. 32, 328-338.

Sear, F. (1987) Roman Architecture. Ithaca: Cornell University Press.

Stambaugh, J. E. (1978) 'The Functions of Roman Temples.' - ANRW II.16.1, 554-608.

Stambaugh, J. E. (1988) The Ancient Roman City. Baltimore: Johns Hopkins University Press.

Steinby, E. M. (1993-2000) Lexicon Topographicum Urbis Romae. Rom: Quasar.

Syme, R. (1939) The Roman Revolution. Oxford: Oxford University Press.

Taylor, L. R. (1949) Party Politics in the Age of Caesar. Berkeley: University of California Press.

Taylor, L. R. (1966) Roman Voting Assemblies: from the Hannibalic War to the Dictatorship of Caesar. Ann Arbor: University of Michigan Press.

Versnel, H. S. (1970) Triumphus: an inquiry into the origin, development and meaning of the Roman triumph. Leiden: Brill.

Ward-Perkins, J. B. (1981) Roman Imperial Architecture. 2nd ed. Markham: Penguin.

Weinstock, S. (1957) 'Victor and Invictus.' - HThR 50, 211-248.

Wiseman, T. P. (1974) 'The Circus Flaminius.' - PBSR 42, 3-26.

Wiseman, T. P. (1985) Roman Political Life, 90 B.C.-A.D. 69. Exeter: Exeter University Press. 